\title{
Different aspects of Lactobacillus inoculants on the improvement of quality and safety of alfalfa silage
}

\author{
Krystyna Zielińska ${ }^{1}$, Agata Fabiszewska ${ }^{2 *}$, and Ilona Stefańska ${ }^{1}$
}

There is a significant range of bacterial inoculants for forage ensiling, but there is still a need for formulations to improve the safety of feed. The objective of the study was to evaluate the usefulness of three lactobacilli strains in alfalfa (Medicago sativa L.) The following bacterial inoculants were used: Lactocacillus plantarum K KKP 593p (LPK), L. plantarum C KKP 788p (LPC), L. buchneri KKP 907p (LB), and mix of all three strains (LPK+LPC+LB). The application of bacterial inoculants in alfalfa ensiling resulted in a reduction of the total number of molds, Clostridium perfringens and Listeria sp. (up to 5, 7, and 5 times respectively for LB inoculant in comparison to untreated silage). Total inhibition of Salmonella sp. and Escherichia coli growth was achieved in silages treated with all inoculants except for LPC. Aerobic stability in the control silage was the lowest $(77 \mathrm{~h})$ and doubled under the influence of bacterial inoculants. The most stable according to aerobic stability was silage treated with LB inoculant $(175 \mathrm{~h})$, where the highest concentrations of acetic acid (4.8 $\mathrm{g}$ $\left.\mathrm{kg}^{-1}\right)$, propionic acid $\left(0.7 \mathrm{~g} \mathrm{~kg}^{-1}\right)$ and 1,2-propanediol $\left(526 \mathrm{mg} \mathrm{kg}^{-1}\right)$ were reported. The study discussed that it is important to evaluate not only the effect of bacterial inoculants on physicochemical and microbiological silage properties, as the presence and expression of antibiotic resistance genes in lactic acid bacteria have been reported. The results of antimicrobial susceptibility testing of the strains showed that almost all minimum inhibitory concentrations values for eight antibiotics were equal to or below the corresponding breakpoints proposed by the European Food Safety Authority, Additives and Products or Substances used in Animal Feed Panel.

Key words: Aerobic stability, alfalfa, antibiotic susceptibility, Lactobacillus, pathogenic bacteria, silage.

\section{INTRODUCTION}

Alfalfa (Medicago sativa L.) is a valuable forage plant characterized by a high content of crude protein. Ensiling is one of the best known methods to preserve fodder, but legumes such as alfalfa have long been regarded as difficult to ensile forages because of their low $(<1.5 \%)$ content of soluble carbohydrates in the fresh material, low dry matter (DM), and high buffering capacity; therefore, the usage of biological or chemical additives is beneficial (Ohshima et al., 1997; Repetto et al., 2011).

Epiphytic microflora of plants is composed of bacteria, including Clostridium sp., Bacillus sp., coliform bacteria and lactic acid bacteria (LAB), as well as yeasts and moulds. The role of lactic acid bacteria in the ensiling process is not only to lower $\mathrm{pH}$ by converting watersoluble carbohydrates into organic acids, but these

${ }^{1}$ Prof. Wacław Dąbrowski Institute of Agricultural and Food Biotechnology, Department of Fermentation Technology, 36 Rakowiecka St., 02-532 Warsaw, Poland.

${ }^{2}$ Warsaw University of Life Sciences, Faculty of Food Sciences, 159 c Nowoursynowska St., 02-787, Warsaw, Poland.

"Corresponding author(agata_fabiszewska@sggw.pl).

Received: 9 September 2014.

Accepted: 24 March 2015.

doi: $10.4067 /$ S0718-58392015000400005 bacteria are also responsible for inhibiting the growth of undesirable epiphytic microorganisms by competing for nutrients and synthesizing antimicrobial and antifungal agents. Different lactic acid bacteria species synthesize some metabolites from those mentioned above, such as bacteriocins, hydrogen peroxide, lactate peroxidase or 1,2-propanediol, all of which inhibit the growth of pathogenic and spoilage bacteria, yeast and moulds (Davies et al., 1996; Magnusson and Schnürer, 2005).

The forage before ensiling intended for silages usually contains a low number of lactic acid bacteria - less than $1 \%$ of the microflora - so it is necessary to apply starter cultures of selected strains of lactic acid bacteria to stimulate the ensiling process (Danner et al., 2003; Schmidt et al., 2009, Zhang et al., 2009). Therefore, the addition of LAB at more than $10^{5} \mathrm{CFU} \mathrm{g}^{-1}$ in silage-making has been recommended in order to effectively reduce DM loss and avoid clostridial fermentation (McDonald et al., 1991; Nishino et al., 2003). Ranjit and Kung (2000) recommended a dose of $10^{6} \mathrm{CFU} \mathrm{g}^{-1}$ for satisfactory improvement. Selected strains of $\mathrm{LAB}$, which are used as silage inoculants, improve the quality and aerobic stability of silages and are often characterized by the probiotic activity in the digestive tract of animals (Oude Elferink et al., 2001; Holzer et al., 2003). Facultative heterolactic acid bacteria such as Lactobacillus plantarum synthesize mainly lactic acid and a few volatile 
fatty acids, which are substrates that are important for the protection of silages from the interference of aerobic yeasts and moulds. Since obligate heterolactic acid bacteria, like L. buchneri, produce higher levels of acetic acid, they can stabilize silages during aerobic exposure (Zhang et al., 2009). Studies estimating the aerobic stability of silage feed prepared with the addition of bacterial starter cultures, in conjunction with the reduction of the development of aerobic microorganisms, were carried out in a number of research institutes in the field of agriculture (Ranjit and Kung, 2000; Taylor et al., 2002; Schmidt et al., 2009). Currently, there is a significant range of bacterial inoculants for forage ensiling on the market, but there is still the need for formulations to improve not only the quality of feed, but also to decrease the content of pathogenic bacteria and moulds and even to decontaminate the silages of mycotoxins produced by them (Zielinska and Miecznikowski, 2008; Richard et al., 2009).

Development of the composition of bacterial silage inoculants is a complex but extraordinary aspect from the economic and technological points of view. The precise characteristic of the ensiled plant material is strongly dependent on lactic acid bacteria microflora, both epiphytic and external, introduced with the preparations. The objective of the study was to evaluate the usefulness of three selected lactobacilli strains in alfalfa ensiling when used separately and in combination. To the best of our knowledge, there are plenty of papers describing the effect of bacterial inoculants in meadow grass silages, alfalfa, sugar cane, maize whole crop and maize corn silages. Most authors have focused on the physical and chemical properties of silages and their effect on silage aerobic stability, ruminal fermentation, and dairy and meat production. The authors of this paper focused on the impact of lactic acid selection to prepare the bacterial inoculant in association with the safety and microbiological quality of alfalfa ensilage. This article emphasizes the rarely discussed issues of potentially pathogenic microbes presence in silages as well as antibiotic resistance in bacterial strains used in silage inoculants. Antibiotic resistance is a serious and growing phenomenon in contemporary biological sciences, wrongly pertained only to pathogenic organisms. Some more frequently discussed issues relevant to genetic identification and production of specific metabolites by lactic acid bacteria are described in the paper too.

\section{MATERIALS AND METHODS}

\section{Bacterial strains and culture conditions}

Three bacterial strains were examined in the study: Lactobacillus plantarum K KKP/593/p (Zielinska et al., 1995), Lactobacillus plantarum C KKP/788/p (Zielinska et al., 1998) and/or Lactobacillus buchneri KKP 907p (Zielinska et al., 2006). All three species were patented and characterized by the different phenotypic features presented in Table 1. The studied strains have been deposited at the Collection of Industrial Microorganisms at the prof. Wacław Dąbrowski Institute of Agricultural and Food Biotechnology in Warsaw (Poland).

Lactic acid bacteria were cultivated on Lactobacilli MRS broth medium (Difco, Becton, Dickinson and Company, Franklin Lakes, New Jersey, USA) at $30{ }^{\circ} \mathrm{C}$ and under aerobic conditions. Bacterial biomass was centrifuged using a Jouan centrifuge (8000 rpm, $\left.10 \mathrm{~min}, 5^{\circ} \mathrm{C}\right)$.

\section{Genetic differentiation of strains and evaluation of antibiotic susceptibility}

Genomic DNA was purified using bacterial genomic DNA kits (GenElut, Sigma-Aldrich, St. Louis, Missouri, USA) following the manufacturer's instructions. Strain-specific identification was performed using RAPD-PCR with different primers, PRIMO2: 5'-CGGCAAGGAG-3', RP: 5'-CAGCACCCAC-3' and M13: 5'-GAGGGTGGCGGTTCT-3'. The reaction mixture contained $10 \mu \mathrm{M}$ of primer, $0.2 \mathrm{mM}$ of each dNTP, $3.5 \mathrm{mM} \mathrm{MgCl}_{2}, 0.625 \mathrm{U}$ Taq DNA polymerase, reaction buffer and $100 \mathrm{ng}$ DNA as a template. PCR was performed under one of the following amplification conditions: initial denaturation at $94{ }^{\circ} \mathrm{C}$ for $4 \mathrm{~min}, 30$ cycles of $94{ }^{\circ} \mathrm{C}$ for 30 $\mathrm{s}, 45^{\circ} \mathrm{C}$ for $30 \mathrm{~s}, 72^{\circ} \mathrm{C}$ for $45 \mathrm{~s}$ and a final extension step at $72{ }^{\circ} \mathrm{C}$ for $7 \mathrm{~min}$ (primer M13) or initial denaturation at $94{ }^{\circ} \mathrm{C}$ for $3 \mathrm{~min}, 35$ cycles of $94{ }^{\circ} \mathrm{C}$ for $45 \mathrm{~s}, 45^{\circ} \mathrm{C}$ for $45 \mathrm{~s}, 72{ }^{\circ} \mathrm{C}$ for $2 \mathrm{~min}$ and a final extension step at

Table 1. Characteristics of bacterial strains used in the study.

\begin{tabular}{|c|c|c|c|c|}
\hline \multirow[b]{2}{*}{ Strain } & \multirow[b]{2}{*}{$\begin{array}{l}\text { Source of } \\
\text { isolation }\end{array}$} & \multicolumn{2}{|c|}{ Specific features } & \multirow[b]{2}{*}{ Reference } \\
\hline & & $\begin{array}{l}\text { Ability to synthesize lactic acid } \\
\text { utilizing different } C \text { sources }\end{array}$ & $\begin{array}{l}\text { Content of lactic acid in modified MRS } \\
\text { medium after } 72 \mathrm{~h} \text { culture }\left(\mathrm{g} \mathrm{kg}^{-1}\right)\end{array}$ & \\
\hline $\begin{array}{l}\text { Lactobacillus plantarum } \mathrm{K} \\
\mathrm{KKP} / 593 / \mathrm{p}\end{array}$ & $\begin{array}{l}\text { Raw potato } \\
\text { silage }\end{array}$ & Native potato starch or native cereal starch & $19.0-30.0$ & $\begin{array}{l}\text { Zielinska et al., } \\
1995\end{array}$ \\
\hline \multirow[t]{2}{*}{ L. plantarum C KKP/788/p } & Alfalfa silage & $\begin{array}{l}\text { Cellulose and/or oat xylan } \\
\text { native potato starch }\end{array}$ & $\begin{array}{l}13.0-14.0 \\
18.0\end{array}$ & $\begin{array}{l}\text { Zielinska et al., } \\
1998\end{array}$ \\
\hline & & Ability to synthesize 1,2-propanediol & $\begin{array}{l}\text { Concentration of 1,2-propanediol during } 10 \mathrm{~d} \text { of } \\
\text { culture in MRS medium, mg } 100 \mathrm{~mL}^{-1} \text { medium }\end{array}$ & \\
\hline L. buchneri KKP $907 \mathrm{p}$ & $\begin{array}{l}\text { Meadow } \\
\text { grass silage }\end{array}$ & Yes & 100 & $\begin{array}{l}\text { Zielinska et al., } \\
2006\end{array}$ \\
\hline
\end{tabular}


$72{ }^{\circ} \mathrm{C}$ for 5 min (primer RP and PRIMO2). PCR products were separated by electrophoresis on a $1.5 \%$ agarose gel (Sigma-Aldrich) stained with fluorescent DNA stain (GelRed, Biotium Inc., Hayward, California, USA). All reactions were performed in three independent studies.

The minimum inhibitory concentrations (MIC) for eight antibiotics (ampicillin, gentamicin, kanamycin, streptomycin, erythromycin, clindamycin, tetracycline, and chloramphenicol) were determined using MuellerHinton II (Cation-Adjusted) Agar (Becton, Dickinson and Company) supplemented with 5\% defibrinated sheep blood. The gradient test method was used for MIC. Evaluator for erythromycin and tetracycline (Oxoid, Basingstoke, Hampshire, UK) and E-test strip for the rest of the antimicrobial agents (bioMérieux, Marcy l'Etoile, France) were used according to the manufacturer's instructions. Inoculum of each strain was prepared by suspending colonies from MRS agar plates in sterile saline to reach a turbidity corresponding to McFarland standard 1. After 24 and $48 \mathrm{~h}$ of incubation of plates under microaerophilic condition $\left(5 \% \mathrm{CO}_{2}\right)$ at $35^{\circ} \mathrm{C}$, MIC values were determined. The susceptibility of strains was established in accordance with the breakpoints proposed by the European Food Safety Authority (EFSA) Panel on Additives and Products or Substances used in Animal Feed (FEEDAP) (EFSA FEEDAP, 2012).

\section{Bacterial inoculants}

The bacterial inoculant contained lactic acid bacteria, carriers and emulsifiers. There were used following carriers: sucrose, glucose, lactose, starch soluble pure and emulsifiers: xanthan gum and lecithin. The preparation was in the dry form of granules characterized by a minimum of $96 \%$ DM. One gram of inoculant contained no less than 2 $\times 10^{10}$ colony forming units $(\mathrm{CFU})$ of the strains. Bacterial inoculants were produced by prof. Wacław Dąbrowski Institute of Agriculture and Food Biotechnology in Warsaw, according to the manufacturing process developed by the company and described by Miecznikowski et al. (2008). Four bacterial inoculants were tested: L. plantarum $\mathrm{K}$ KKP 593p (LPK), L. plantarum C KKP 788p (LPC), L. buchneri KKP 907p (LB), and a mixture of all three strains $(\mathrm{LPK}+\mathrm{LPC}+\mathrm{LB})$.

\footnotetext{
Alfalfa ensiling

Alfalfa was harvested and collected for ensiling. The trial was conducted under farm conditions at the experimental Station at Falenty near Warsaw, Poland. The alfalfa field was cut at the initial flowering in times (two cut). The first cut was not studied. The herbage was mown with a rotary mower-conditioner and before harvest was pre-wilted to a DM about $30 \%$. The material was chopped to $1.5 \mathrm{~cm}$ lengths. Following chopping, the plants were ensiled in polyethylene microsilos of $0.01 \mathrm{~m}^{3}$ capacity, sealed with a rubber stopper allowing the release of gaseous products. Forages were treated and untreated with bacterial
}

inoculants. All experiments were provided using the lowest dose of the bacterial inoculant, which is $10 \mathrm{~g} \mathrm{t}^{-1}$ of forage before ensiling (alfalfa) or $2 \times 10^{5} \mathrm{CFU} \mathrm{g}^{-1}$ of raw plant material. Silages untreated with bacterial inoculants were used as a control material. Silos were kept in a room at a temperature of $20 \pm 2{ }^{\circ} \mathrm{C}$ for $90 \mathrm{~d}$. Once the silo was opened, it was removed from the subsequent experiment. Experiments were made in triplicate, what meant that three silos were prepared for each treatment.

\section{Chemical and microbial analyses of silages}

Silage samples were analyzed after $90 \mathrm{~d}$ of ensiling. The extract of macerated silage was prepared with distilled water and filtered through two layers of cheesecloth. An adjusted DM content was determined according to ISO standard (PN-ISO 6496: 2002) and $\mathrm{pH}$ using the potentiometric method. Determination of L- and D-lactic acid content, acetic and 3-hydroxybutyric acid contents were conducted by enzymatic methods according to the manufacturer's protocols (Boehringer Mannheim, Germany). Ammonia N concentration was determined by the Convay method (Skulimowski, 1974) and the determination of ethanol content was performed by the Weissbach-Laube method (Weissbach and Laube, 1964). To measure the content of soluble carbohydrates, the NIRS method was used (NIRFlex N-500 spectrometer, Büchi Labortechnik, Flawil, Switzerland, the ready-touse INGOT calibrations were chosen).

Propionic acid and 1,2-propanediol were determined by gas chromatograph with a flame ionization detector (FID) (7890A GC, Agilent Technologies, Santa Clara, California, USA) and a capillary column with a diameter of $0.53 \mathrm{~mm}$ and a length of $30 \mathrm{~m}$ with phase J\&W DBFFAP column (Agilent). Test samples were previously purified by solid phase extraction on a SPE- $\mathrm{C}_{18}$ column and then analyzed using chromatographic techniques. Helium was used as a carrier gas with a flow rate of 85 $\mathrm{mL} \mathrm{min}^{-1}$ and the following temperature program: $35^{\circ} \mathrm{C}$ $(0.5 \mathrm{~min})$, with an increase of $20^{\circ} \mathrm{C} \mathrm{min}^{-1}$ to $90^{\circ} \mathrm{C}$, and an increase of $10^{\circ} \mathrm{C} \mathrm{min}{ }^{-1}$ to $200{ }^{\circ} \mathrm{C}(0.5 \mathrm{~min})$. Chemstation Agilent Technologies B.03.01 software was used.

Then, $10 \mathrm{~g}$ fresh forage and silages were homogenized in $100 \mathrm{~mL}$ sterile peptone water, mixed vigorously for $60 \mathrm{~min}$ and used for culturing. Subsequent serial 10fold dilutions were made, to obtain 15-300 colonies per dish. All microorganisms were determined in triplicate. Lactic acid bacteria were enumerated by pour plating of MRS medium according to ISO standard (PN-ISO 15214:2002). The number of moulds was determined by the plate method according to the ISO standard (PN-ISO 21527-2:2009) and the number of yeasts was determined using an YPG medium with chloramphenicol. Salmonella sp. were enumerated by a plate method with the use of Rambach Agar (Merck, New Jersey, USA) and Clostridium perfringens by a plate method on selective medium Agar Base 9188 (Neogen, Lansing, 
Michigan, USA) according to the ISO standard (PN-EN ISO 7937:2005). Determination of Escherichia coli and coliform bacteria was done using a plate method with the use of technical medium (3M Petrifilm E. coli/Coliforms count plates, Noack, Vienna, Austria).

Determination of genera and species of yeast was performed after the selection and multiplication of pure cultures, using the API $20 \mathrm{C}$ AUX and mini-API identification tests (bioMérieux).

\section{Aerobic stability}

Determination of storage stability was performed according to a temperature method described by Honig (1985). The experiment was conducted for $10 \mathrm{~d}$ at 20 $\pm 1{ }^{\circ} \mathrm{C}$ with an excess of oxygen. Silages were kept in plastic containers with a volume of $10 \mathrm{dm}^{3}$. Temperature measurements in silages were detected at $1 \mathrm{~h}$ and a temperature increase of $3{ }^{\circ} \mathrm{C}$ was considered to be an indication of instability.

\section{Statistical analysis}

Statistical analyses of the results were performed by repeated measurements with one-way ANOVA in STATISTICA 8.0 (StatSoft, Krakow, Poland), followed by Tukey's multiple comparison test. P-values of $\mathrm{P} \leq 0.05$ were considered significant. The Shapiro-Wilk test was used to determine whether the population was normally distributed. Levene's test and Brown-Forsythe test were used to assess the equality of variances for a variable calculated for groups.

\section{RESULTS}

\section{Genetic differentiation of strains and evaluation of antibiotic susceptibility}

In the present study, the LAB strains were characterized on the basis of genetic diversity and important safety properties. RAPD-PCR analysis with three different primers was used to evaluate the genetic diversity and genetic stability among the studied lactobacilli strains. RAPD-PCR produced patterns with products ranging from approximately $300 \mathrm{bp}$ (primer PRIMO2) or $600 \mathrm{bp}$ (primer RP) to more than 3000 bp (Figure 1). All three strains were distinguished from each other on the basis of specific and reproducible RAPD profiles, indicating a high diversity among isolates (Figure 1). Using this method, the genetic stability of selected strains during a short time period was also confirmed.

The results of antimicrobial susceptibility testing of studied strains using the E-test are shown in Table 2. Almost all MIC values were equal to or below the corresponding breakpoints proposed by EFSA FEEDAP Panel. Only for L. buchneri KKP/907/p was an MIC value for one antibiotic above the EFSA recommendation (16

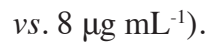

\section{Effect of bacterial inoculants on physicochemical and microbiological quality of alfalfa silage}

The effect of bacterial inoculants on physicochemical and microbiological quality of alfalfa silages was evaluated. The average DM for raw alfalfa was $294.0 \mathrm{~g}$

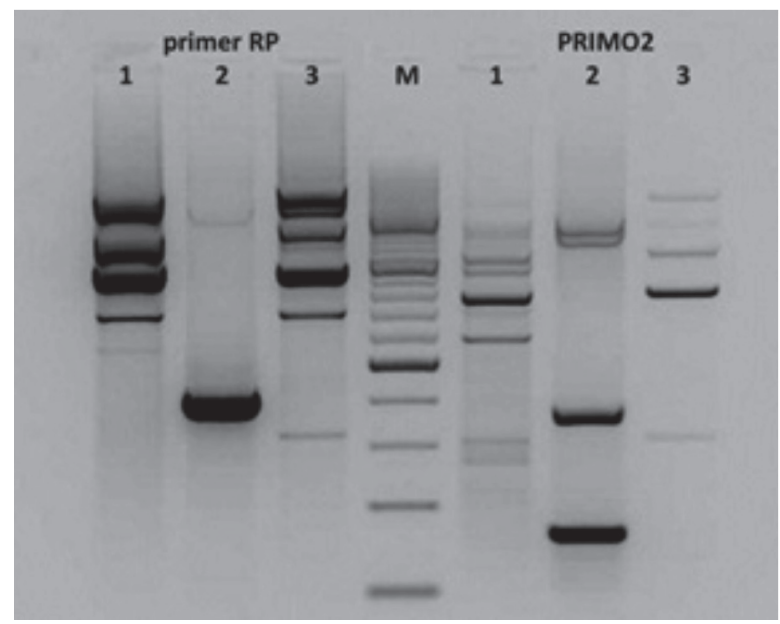

Figure 1. RAPD patterns obtained with primer RP and PRIMO2. Lane 1: DNA template from Lactobacillus plantarum KKP/593/p; lane 2: DNA template from $L$. plantarum KKP/788/p; lane 3: DNA template from L. buchneri KKP/907/p; lane M: O'RangeRuler 200 bp DNA Ladder (ThermoScientific, the brighter bands at 3000, 2000, and 1000 bp serve as reference bands).

Table 2. Antimicrobial susceptibilities of the tested strains .

\begin{tabular}{|c|c|c|c|c|c|c|c|c|}
\hline \multirow[b]{3}{*}{ Antibiotics } & \multicolumn{8}{|c|}{ Minimum inhibitory concentrations (MIC) values $\left(\mathrm{mg} \mathrm{L}^{-1}\right)$} \\
\hline & \multicolumn{2}{|c|}{$\begin{array}{c}\text { Lactobacillus plantarum } \\
\text { K KKP } / 593 / p\end{array}$} & \multicolumn{2}{|c|}{$\begin{array}{l}\text { L. plantarum } \mathrm{C} \\
\mathrm{KKP} / 788 / \mathrm{p}\end{array}$} & \multirow[b]{2}{*}{ EFSA $^{a}$} & \multicolumn{2}{|c|}{$\begin{array}{l}\text { Lactobacillus buchneri } \\
\text { KKP 907p }\end{array}$} & \multirow[b]{2}{*}{ EFSA $^{b}$} \\
\hline & $24 \mathrm{~h}$ & $48 \mathrm{~h}$ & $24 \mathrm{~h}$ & $48 \mathrm{~h}$ & & $24 \mathrm{~h}$ & $48 \mathrm{~h}$ & \\
\hline Ampicillin & 0.50 & 0.75 & 0.19 & 0.19 & 2 & $\mathrm{ng}$ & 0.38 & 2 \\
\hline Gentamycin & 1.00 & 1.50 & 1.00 & 1.00 & 16 & ng & 0.125 & 16 \\
\hline Kanamycin & 24.00 & 32.00 & 24.00 & 24.00 & 64 & ng & 4.0 & 32 \\
\hline Streptomycin & 16.00 & 24.00 & 18.00 & 24.00 & $\mathrm{nr}$ & ng & 2.0 & 64 \\
\hline Erythromycin & 0.12 & 0.25 & 0.12 & 0.25 & 1 & ng & $<0.015$ & 1 \\
\hline Clindamycin & 0.38 & 0.75 & 0.25 & 0.25 & 2 & ng & $<0.016$ & 1 \\
\hline Tetracycline & 4.00 & 8.00 & 8.00 & 16.00 & 32 & ng & $16.0 \mathrm{c}$ & 8 \\
\hline Chloramphenicol & 6.00 & 8.00 & 6.00 & 6.00 & 8 & ng & 2.0 & 4 \\
\hline
\end{tabular}

nr: Not required; ng: no growth.

${ }^{a}$ European Food Safety Authority recommendation for Lactobacillus plantarum/pentosus.

bEuropean Food Safety Authority recommendation for Lactobacillus obligate heterofermentative.

${ }^{c}$ Value above European Food Safety Authority recommendation. 
$\mathrm{kg}^{-1} \mathrm{DM}$ and the average content of soluble carbohydrate was $14.8 \mathrm{~g} \mathrm{~kg}^{-1}$ (Table 3). After $90 \mathrm{~d}$ of ensiling, the greatest decrease of silage DM occurred in the control silage prepared without the addition of inoculants $(5.4 \%)$. The lowest decrease was observed for the silage treated with inoculant containing three Lactobacillus strains (LPK+LPC+LB) (4.0\%). Alfalfa ensiled without bacterial inoculants was characterized by high $\mathrm{pH}$ (4.8), while the tested bacterial preparations had an important impact on $\mathrm{pH}$ reduction to 4.0-4.2. Also, other measured physicochemical parameters of alfalfa silage quality, like content of organic acids, amount of ethanol and ammonia $\mathrm{N}$, were the least preferred for silages untreated with a Lactobacillus starter culture. In addition, selected strains influenced butyric acid fermentation, which was inhibited in silages treated with bacterial inoculants. In the case of inoculant LB, there was also a noticeable increase in the content of acetic acid $\left(4.8 \mathrm{~g} \mathrm{~kg}^{-1}\right)$ and propionic acid $(0.7$ $\mathrm{g} \mathrm{kg}^{-1}$ ) in relation to the other variants of experiment (4.0$4.4 \mathrm{~g} \mathrm{~kg}^{-1}$ acetic acid and $0.4-0.5 \mathrm{~g} \mathrm{~kg}^{-1}$ propionic acid for silages prepared with $\mathrm{LC}, \mathrm{LK}$, and mixed inoculants). The addition of LAB starter cultures reduced the ammonia $\mathrm{N}$ content (from $97.0 \mathrm{~g} \mathrm{~kg}^{-1}$ in control alfalfa silage to $69.0-75.0 \mathrm{~g} \mathrm{~kg}^{-1}$ for inoculated silages) and increased the content of water-soluble carbohydrates (from $2.2 \mathrm{~g} \mathrm{~kg}^{-1}$ in control alfalfa silage to $3.5 \mathrm{~g} \mathrm{~kg}^{-1}$ for silage prepared with mixed inoculant and 5.2 for silage prepared with LPK inoculant) (Table 3).

The $\mathrm{pH}$ value of control silage was lower in all silages treated with bacterial inoculants (4.8vs. 4.0-4.2) (Table 4). Aerobic stability in the control silage was the lowest $(77 \mathrm{~h})$ and doubled under the influence of bacterial inoculants. Moreover, the bacterial treated silages characterized by very varied aerobic stability, from $141 \mathrm{~h}$ for $\mathrm{LC}$ treatment to $175 \mathrm{~h}$ for $\mathrm{LB}$ treatment.

The results of the physicochemical analysis of ensiled plant material were in accordance with the characteristics of individual bacteria strains. As well as soluble carbohydrates, alfalfa contains starch, cellulose and xylans; therefore, bacteria capable of partial hydrolysis of these compounds may develop more intensively in ensiled plants. The selected bacterial strains have a unique capability to synthesize amylolytic enzymes $(L$. plantarum K KKP/593/p) and cellulolytic enzymes (such as the strain of L.plantarum C), and they are also capable of lactic acid synthesis from xylan (L. plantarum C KKP 788p) and the efficient synthesis of 1,2-propanediol as the strain of L. buchneri (Zielinska et al., 1995; 1998; 2006).

In control silages prepared without the addition of inoculants, the number of Salmonella sp., Clostridium

Table 3. Chemical composition of alfalfa silages untreated and treated with inoculants of Lactobacillus strains.

\begin{tabular}{|c|c|c|c|c|c|}
\hline & \multicolumn{5}{|c|}{ Ensiled alfalfa } \\
\hline & \multirow[b]{2}{*}{$\begin{array}{l}\text { Untreated } \\
\text { control }\end{array}$} & \multicolumn{4}{|c|}{ Treated with bacterial inoculants } \\
\hline & & $\begin{array}{l}\text { L. plantarum } \\
\text { K KKP } 593 \text { p } \\
\text { (LPK) }\end{array}$ & $\begin{array}{l}\text { L. plantarum C } \\
\text { KKP } 788 \mathrm{p} \\
\text { (LPC) }\end{array}$ & $\begin{array}{l}\text { L. buchneri } \\
\text { KKP } 907 \text { p } \\
\text { (LB) }\end{array}$ & $\begin{array}{c}\text { Lactic acid bacteria } \\
\operatorname{mix} \\
(\mathrm{LPK}+\mathrm{LPC}+\mathrm{LB})\end{array}$ \\
\hline Dry matter, $\mathrm{g} \mathrm{kg}^{-1}$ & $278.2 \pm 2.0 \mathrm{a}$ & $281.4 \pm 0.7 \mathrm{a}$ & $280.7 \pm 0.6 \mathrm{a}$ & $280.6 \pm 1.3 \mathrm{a}$ & $282.5 \pm 1.6 \mathrm{a}$ \\
\hline $\mathrm{pH}$ & $4.8 \pm 0.1 \mathrm{a}$ & $4.1 \pm 0.1 b$ & $4.2 \pm 0.1 b$ & $4.1 \pm 0.1 b$ & $4.0 \pm 0.1 \mathrm{~b}$ \\
\hline Concentration lactic acid, $\mathrm{g} \mathrm{kg}^{-1}$ & $8.2 \pm 0.2 \mathrm{a}$ & $17.5 \pm 0.2 \mathrm{~d}$ & $15.2 \pm 0.4 \mathrm{c}$ & $13.3 \pm 0.4 \mathrm{~b}$ & $16.5 \pm 0.4 \mathrm{~d}$ \\
\hline \multicolumn{6}{|l|}{ Concentration volatile fatty acids, $\mathrm{g} \mathrm{kg}^{-1}$} \\
\hline Acetic acid & $3.8 \pm 0.1 \mathrm{ab}$ & $4.2 \pm 0.1 b c$ & $4.4 \pm 0.1 \mathrm{a}$ & $4.8 \pm 0.2 \mathrm{c}$ & $4.0 \pm 0.1 \mathrm{abc}$ \\
\hline 3-Hydroxybutyric acid & $1.0 \pm 0.2 \mathrm{a}$ & $0.1 \pm 0.0 b$ & $0.2 \pm 0.0 \mathrm{~b}$ & $0.1 \pm 0.1 b$ & $0.2 \pm 0.1 \mathrm{~b}$ \\
\hline Propionic acid & $0.2 \pm 0.0 \mathrm{a}$ & $0.5 \pm 0.0 \mathrm{~b}$ & $0.4 \pm 0.1 \mathrm{ab}$ & $0.7 \pm 0.1 \mathrm{c}$ & $0.4 \pm 0.0 \mathrm{ab}$ \\
\hline Lactate/acetate ratio & $2.2 \pm 0.1 \mathrm{a}$ & $4.1 \pm 0.1 \mathrm{c}$ & $3.3 \pm 0.1 \mathrm{c}$ & $2.8 \pm 0.1 b$ & $4.1 \pm 0.1 \mathrm{c}$ \\
\hline Concentration 1,2-propanediol, $\mathrm{mg} \mathrm{kg}^{-1}$ & No detectable a & $92.0 \pm 2.0 b$ & $84.0 \pm 6.0 b$ & $526.0 \pm 28.0 \mathrm{~d}$ & $230.0 \pm 12.0 \mathrm{c}$ \\
\hline Concentration alcohols (ethanol), $\mathrm{g} \mathrm{kg}^{-1}$ & $7.6 \pm 0.2 \mathrm{a}$ & $2.2 \pm 0.3 b$ & $2.9 \pm 0.1 b$ & $2.7 \pm 0.6 b$ & $2.8 \pm 0.8 b$ \\
\hline Concentration ammonia $\mathrm{N}, \mathrm{NH}_{3}-\mathrm{N} / \mathrm{TN}, \mathrm{g} \mathrm{kg}^{-1}$ & $97.0 \pm 9.9 \mathrm{a}$ & $69.0 \pm 0.3 b$ & $75.0 \pm 5.0 \mathrm{~b}$ & $73.0 \pm 4.0 \mathrm{ab}$ & $74.0 \pm 5.0 \mathrm{~b}$ \\
\hline Concentration of water-soluble carbohydrates, $\mathrm{g} \mathrm{kg}^{-1}$ & $2.2 \pm 0.2 \mathrm{a}$ & $5.2 \pm 0.2 \mathrm{c}$ & $3.9 \pm 0.2 b$ & $3.6 \pm 0.1 b$ & $3.5 \pm 0.3 b$ \\
\hline
\end{tabular}

Distinct letters in the row indicate significant differences according to Tukey's test $(\mathrm{P} \leq 0.05)$.

\pm Standard deviation.

Table 4. Comparison of silages treated and untreated with bacterial inoculants according to aerobic stability, number of moulds, and number and genus of yeast.

\begin{tabular}{|c|c|c|c|c|c|c|}
\hline & \multirow[b]{3}{*}{ Raw alfalfa } & \multicolumn{5}{|c|}{ Ensiled alfalfa } \\
\hline & & \multirow[b]{2}{*}{$\begin{array}{c}\text { Untreated } \\
\text { control }\end{array}$} & \multicolumn{4}{|c|}{ Treated with bacterial inoculants } \\
\hline & & & $\begin{array}{l}\text { Lactobacillus } \\
\text { plantarum } \\
\text { K KKP } 593 \text { p } \\
\text { (LPK) }\end{array}$ & $\begin{array}{l}\text { L. plantarum C } \\
\text { KKP } 788 \text { p } \\
\text { (LPC) }\end{array}$ & $\begin{array}{l}\text { L. buchneri } \\
\text { KKP } 907 \text { p } \\
\text { (LB) }\end{array}$ & $\begin{array}{c}\text { Lactic acid bacteria } \\
\text { mix } \\
(\mathrm{LPK}+\mathrm{LPC}+\mathrm{LB})\end{array}$ \\
\hline $\begin{array}{l}\text { Aerobic stability, } \mathrm{h} \\
\text { Number of moulds, } \log \mathrm{CFU} \mathrm{g} \mathrm{g}^{-1} \\
\text { Number of yeast, } \log \mathrm{CFU} \mathrm{g} \mathrm{g}^{-1}\end{array}$ & $\begin{array}{c}- \\
4.40 \pm 0.14 \mathrm{a} \\
1.37 \pm 0.12 \mathrm{ab}\end{array}$ & $\begin{array}{c}77 \pm 3 \mathrm{a} \\
4.89 \pm 0.34 \mathrm{a} \\
2.59 \pm 0.78 \mathrm{a}\end{array}$ & $\begin{array}{l}157 \pm 3 c \\
1.02 \pm 0.15 b \\
0.95 \pm 0.26 b\end{array}$ & $\begin{array}{l}141 \pm 3 b \\
1.56 \pm 0.31 b \\
1.03 \pm 0.17 b\end{array}$ & $\begin{array}{l}175 \pm 3 \mathrm{~d} \\
0.86 \pm 0.17 \mathrm{~b} \\
1.19 \pm 0.13 \mathrm{ab}\end{array}$ & $\begin{array}{l}155 \pm 5 c \\
1.53 \pm 0.27 b \\
0.77 \pm 0.56 b\end{array}$ \\
\hline Identified genus and yeast species & $\begin{array}{c}\text { Saccharomyces cerevisiae } \\
\text { Candida pelliculosa }\end{array}$ & $\begin{array}{l}\text { S. cerevisiae } \\
\text { C. pelliculosa } \\
\text { C. globosa } \\
\text { C. zeylanoides }\end{array}$ & $\begin{array}{l}\text { C.pelliculosa } \\
\text { C.lambica }\end{array}$ & $\begin{array}{l}\text { C. pelliculosa } \\
\text { C.zeylanoides } \\
\quad \text { C. krusei }\end{array}$ & $\begin{array}{l}\text { C.pelliculosa } \\
\text { C.lambica }\end{array}$ & $\begin{array}{l}\text { C.pelliculosa } \\
\text { C.lambica }\end{array}$ \\
\hline
\end{tabular}

Distinct letters in the row indicate significant differences according to Tukey's test $(\mathrm{P} \leq 0.05) \pm$ Standard deviation. 
perfringens and E. coli increased. The number of Salmonella sp., C. perfringens and E. coli in inoculatedtreated silages were numerically lower than in control one, but no significant difference was found (Table 5). The number of Listeria sp. remained at a similar level in comparison to raw plant material, while the number of coliform bacteria was twice as low (5.42 $\log _{\mathrm{CFU} \mathrm{g}}{ }^{-1}$ for forage before ensiling and $2.40 \mathrm{log} \mathrm{CFU} \mathrm{^{-1 }}$ for control silage). The application of bacterial inoculants in alfalfa ensiling resulted in a reduction in the total number of undesirable microorganisms $(\mathrm{P}<0.05)$, including Listeria sp. and $C$. perfringens. Additionally, silage treatment with LPK, LB, and mix inoculants resulted in the elimination of pathogenic bacteria of the genus Salmonella and bacteria of the species E. coli below detectable levels (Table 5). Silages inoculated with LC preparation were contaminated with Salmonella sp. and E. coli to a small degree (0.23 and $0.22 \log \mathrm{CFU} \mathrm{g}{ }^{-1}$, respectively). There were no significant differences observed regarding the efficiency of particular bacterial inoculants in inhibiting the tested pathogenic bacteria: $C$. perfringens, Listeria sp., and coliform bacteria.

Alfalfa silage prepared without the addition of inoculants was characterized by higher $\mathrm{pH}$ value, and higher amounts of moulds and yeasts than in the forage before ensiling, while under the action of the tested bacteria, there was a decrease $(\mathrm{P}<0.05)$ in the number of those microorganisms (from 0.86 to $1.53 \mathrm{log}_{\mathrm{CFU} \mathrm{g}}{ }^{-1}$ for moulds and from 0.77 to $1.19 \log \mathrm{CFU} \mathrm{g}{ }^{-1}$ for yeast in treated silages vs. 4.89 and $2.59 \log \mathrm{CFU} \mathrm{g}^{-1}$ in the control, respectively). The most active in inhibiting the growth of mould and yeast strains proved to be LPK and LB inoculants, while in the case of yeast, a synergistic effect of the three strains in the mix inoculant was observed, but those differences were not significant (Table 4). The following yeast species were present in the forage before ensiling intended for ensiling as well as in control silages prepared without the addition of bacterial inoculants: Saccharomyces cerevisiae (yeast which ferment sugars) and Candida species including C. pelliculosa (Table 4). Meanwhile, the addition of bacterial inoculants to silage resulted in changes in yeast composition. In inoculated silages, yeasts of the genus Candida were identified, in particular of the species C. pelliculosa and C. lambica, both of which are able to ferment lactate.

\section{DISCUSSION}

Modern diets of ruminants contain major proportions of roughages on a DM basis. Roughage levels can vary between $30 \%$ and $100 \%$ in dairy diets and between $10 \%$ and $100 \%$ in beef diets. Processing roughages by the addition of microbial inoculants can optimize silage quality, and cause an immediate decrease in the $\mathrm{pH}$ to prevent growth of undesirable microorganisms; for that reason, the subject is worth considering (Danner et al., 2003; Nikkhah, 2013).

The precise characteristic of the strain is a key step in the selection of the optimal starter cultures. Identification at the intraspecies level is an important issue since it may help to distinguish strains with relevant properties and assess the genetic stability of starter cultures over time. Bacterial identification at the species level was performed by amplification of the 16S rDNA gene using standard PCR amplification conditions (data not shown). In the present study, all three strains were distinguished from each other by their RAPD profiles (Figure 1). RAPD-PCR analysis has been widely presented as an efficient and rapid tool for the evaluation of genetic diversity within lactobacilli strains which are not easy to differentiate using conventional methods (Aymerich et al., 2006; Markiewicz et al., 2010). It can also be used to monitor a selected starter culture in inoculated silage, to follow the growth, survival, and predominance of a strain (Plengvidhya et al., 2004).

Lactic acid bacteria has GRAS status (generally recognized as safe); however, the presence and expression of antibiotic resistance genes in LAB have been reported (Ouoba et al., 2008; Nawaz et al., 2011). Antibiotic resistance genes of lactic acid bacteria can potentially be transferred to the commensal flora of human and animals and to opportunistic and/or pathogenic bacteria. Therefore, it is very important to verify that LAB strains used in the preparation of fermented products which are not heattreated prior to consumption (including silages) are free of acquired antimicrobial resistance properties and are

Table 5. Inhibition of undesirable bacteria in alfalfa silages treated and untreated with bacterial inoculants.

\begin{tabular}{|c|c|c|c|c|c|c|}
\hline & \multirow[b]{3}{*}{$\begin{array}{l}\text { Alfalfa before } \\
\text { ensiling }\end{array}$} & \multicolumn{5}{|c|}{ Ensiled alfalfa } \\
\hline & & \multirow[b]{2}{*}{$\begin{array}{l}\text { Untreated } \\
\text { control }\end{array}$} & \multicolumn{4}{|c|}{ Treated with bacterial inoculants } \\
\hline & & & $\begin{array}{l}\text { L. plantarum } \\
\text { K KKP } 593 \text { p } \\
\text { (LPK) }\end{array}$ & $\begin{array}{l}\text { L. plantarum C } \\
\text { KKP } 788 \mathrm{p} \\
\text { (LPC) }\end{array}$ & $\begin{array}{l}\text { L. buchneri } \\
\text { KKP } 907 \text { p } \\
\quad \text { (LB) }\end{array}$ & $\begin{array}{c}\text { Lactic acid bacteria } \\
\text { mix } \\
(\mathrm{LPK}+\mathrm{LPC}+\mathrm{LB})\end{array}$ \\
\hline & \multicolumn{6}{|c|}{ Number of bacteria, $\log \mathrm{CFU} \mathrm{g}^{-1}$} \\
\hline Salmonella sp. & $0.80 \pm 0.58 \mathrm{ab}$ & $1.26 \pm 0.20 \mathrm{a}$ & $0.0 \mathrm{~b}$ & $0.23 \pm 0.20 b$ & $0.0 \mathrm{~b}$ & $0.0 \mathrm{~b}$ \\
\hline Escherichia coli & $0.48 \pm 0.34 \mathrm{ab}$ & $1.08 \pm 0.17 \mathrm{a}$ & $0.0 \mathrm{~b}$ & $0.22 \pm 0.31 b$ & $0.0 \mathrm{~b}$ & $0.0 \mathrm{~b}$ \\
\hline Coliform bacteria & $5.42 \pm 0.14 \mathrm{a}$ & $2.40 \pm 0.13 b$ & $0.62 \pm 0.29 \mathrm{c}$ & $0.88 \pm 0.06 \mathrm{c}$ & $0.92 \pm 0.07 \mathrm{c}$ & $0.66 \pm 0.31 \mathrm{c}$ \\
\hline Clostridium perfringens & $1.43 \pm 0.61 \mathrm{ab}$ & $2.13 \pm 0.15 a$ & $0.45 \pm 0.10 \mathrm{c}$ & $0.83 \pm 0.04 \mathrm{bc}$ & $0.31 \pm 0.02 \mathrm{c}$ & $0.36 \pm 0.06 \mathrm{c}$ \\
\hline Listeria sp. & $3.61 \pm 0.18 \mathrm{a}$ & $3.46 \pm 0.04 \mathrm{a}$ & $0.73 \pm 0.08 b$ & $1.16 \pm 0.09 \mathrm{~b}$ & $1.01 \pm 0.15 b$ & $0.87 \pm 0.22 b$ \\
\hline
\end{tabular}

Distinct letters in the row indicate significant differences according to Tukey's test $(\mathrm{P} \leq 0.05) \pm$ Standard deviation. 
thus safe for humans and animals (Klare et al., 2007). In the present study, the MIC values obtained were situated in the examined concentration range and in most cases did not exceed the breakpoints defined by the European Food Safety Authority (EFSA, Parma, Italy). The exception was tetracycline for L. buchneri KKP/907/p, with an MIC value of $16 \mu \mathrm{g} \mathrm{mL}^{-1}$. Although this is one dilution above the EFSA breakpoint $\left(8 \mu \mathrm{g} \mathrm{mL}^{-1}\right)$, this value is not considered to be of concern (EFSA FEEDAP, 2011). The obtained results confirmed that all tested bacterial strains can be safely used as technological additives for feed ensiling.

Microbial silage inoculants can alter many parameters of silages, but the strength of the effect of bacterial inoculants is dependent on strain characteristics. It could be seen that all of the tested bacterial inoculants had a positive effect on many physicochemical properties of silages; e.g. lactic acid content, volatile fatty acids content, ammonia $\mathrm{N}$ or carbohydrates concentrations, $\mathrm{pH}$ and storage stability. Observed effects were in accordance with other authors' results. Muck and Kung (1997) reported that microbial inoculation lowered $\mathrm{pH}$, improved the lactic:acetic ratio, and lowered the ammonia $\mathrm{N}$ content in more than $60 \%$ of studies. Moreover, it was established that microbial inoculants can alter different aspects of silage fermentation such as volatile fatty acids concentrations, fiber digestibility or DM content (Muck and Kung, 1997). Lactobacillus plantarum inoculant preserved more true proteins during silage fermentation than control, which in turn increased in vitro ruminal microbial growth. The inoculant had lower concentrations of ammonia- $\mathrm{N}$ and alfalfa silage $\mathrm{pH}$ and no 3-hydroxybutyric acid was detected in any of the silages (ContrerasGovea et al., 2013). Jatkauskas et al. (2013) reported that homofermentative and heterofermentative lactic acid bacteria inoculants (L. buchneri, L. buchneri in combination with Enterococcus faecium and $L$. plantarum, E. faecium in combination with L. plantarum and Lactococcus lactis) were able to reduce $\mathrm{pH}$, formation of butyric acid, alcohols and ammonia- $\mathrm{N}$ in grass, clovergrass, alfalfa, and maize silages. It was observed that the aerobic stability of silages was improved $(\mathrm{P}<0.05)$ (Jatkauskas et al., 2013).

Ohshima et al. (1997) presented the improvement of alfalfa silage quality by the addition of $L$. casei at $20{ }^{\circ} \mathrm{C}$, but the more effective additive was shown to be previously fermented juice. It was quite understandable that in previously fermented juice there was a full composition of LAB strains with different features, which proved its effectiveness in alfalfa ensiling (Ohshima et al., 1997). This is an important conclusion that makes mixed bacterial starter cultures more attractive from technological point of view.

In well-packed silage forages and those prepared with good agricultural practice, oxygen is rapidly depleted and the activities of aerobic microorganisms are inhibited within a few days of ensiling (Levital et al., 2009). The microbiological quality of silage depends largely also on DM content of the plant. If is too low (below 20\%), clostridia and L. monocytogenes bacteria may develop. In order to improve the quality of roughages, there is a need to eliminate contamination with the spoilage of Clostridium sp. and pathogenic bacteria such as E. coli and Salmonella sp., as well as moulds, which negatively affect the physicochemical quality of forage and the health and welfare of animals (Purwin et al., 2006).

The ability to inhibit the growth of pathogenic bacteria is represented by certain strains of the species, as follows: Lactococcus lactis, Streptococcus lactis, Lactobacillus acidophilus, L. plantarum, L. brevis, L. acidophilus, or L. buchneri (Dimova, 2008). Inhibition of the growth of pathogenic bacteria, yeasts and moulds may be the result of the synergistic action of the produced metabolites: bacteriocins, lactic acid, acetic acid, hydrogen peroxide, lactate peroxidase, lysozyme, reuterin, and propylene glycol (Magnusson and Schnürer, 2005). Moreover, these abilities are strain-dependent. A key factor which decides that lactic acid bacteria inhibit the growth of undesirable bacteria in silage is the rapid generation of a low $\mathrm{pH}$ by production of organic acids, primarily lactic acid. Nevertheless, other factors may add to this.

The inhibition of undesirable microorganisms of Salmonella sp., E. coli, and coliform bacteria was confirmed under in vitro experiments for the mix inoculant which consisted of LK, LC, and LB starter cultures (Zielinska et al., 2011). According to the results in this paper, those abilities were also acknowledged in silo conditions for a mixed inoculant and for LC, LK, and LB inoculants separately. The use of a starter culture of L. buchneri was shown to inhibit the growth of yeast during ensiling (Ranjit and Kung, 2000; Oude Elferink et al., 2001), but in the present study, there was no difference $(\mathrm{P}>0.05)$ among other tested inoculants (LC, LK, and mix) in comparison to LB inoculant. Importantly, LB treatment caused the greatest decrease in the number of moulds in alfalfa silage, but the reduction was not different $(\mathrm{P}>0.05)$.

Bacteria of the order Enterobacteriaceae and genus Clostridium are introduced into soil through organic fertilizer. Thus introduced, the microbes multiply in the green fodder and in silages produced from it (Davies et al., 1996; Holley et al., 2006; You et al., 2006). Ruminants are recognized to be a major reservoir of Shiga toxinproducing E. coli (Duniere et al., 2011). The combination of proper ensiling techniques and the utilization of selected bacterial inoculants appears to represent a good strategy to guarantee nutritional qualities of cattle feed while at the same time limiting the entry of pathogenic bacteria e.g. E. coli into the epidemiological cycle to improve the microbial safety of the food chain (Duniere et al., 2011). The addition of three bacterial inoculants, Propionibacterium sp., L. buchneri, and Leuconostoc 
mesenteroides $\left(10^{6} \mathrm{CFU} \mathrm{g}^{-1}\right)$, was evaluated by Duniere et al. (2011) for their abilities to control E. coli pathogen in corn silages. During ensiling, bacterial treatments did not significantly affect $E$. coli $\mathrm{O} 26$ elimination compared with the negative control, except for the L. buchneri, which showed E. coli strain-dependent inhibition (Duniere et al., 2011).

There can be found a comprehensive literature on pathogenic bacteria elimination (Salmonella sp. and $E$. coli) on alfalfa seeds by high pressure treatment (Hudaa et al., 2009). Unfortunately there are no studies on lowering the number of pathogenic bacteria in alfalfa silage by lactic acid bacteria application. Nevertheless the results presented in the study can be confirmed by similar experiments provided in meadow sward silage inoculated with the bacterial-mineral-vitamin, which consisted of the same lactobacilli strains. There were detected bacteria Salmonella sp. and E. coli accompanied with a high number of coliform bacteria in the silages prepared without the addition of the preparation, while in the silages made with addition of the preparation there were not present any bacteria of the genus Salmonella. The number of coliform bacteria and Escherichia coli was approximately 100 -fold lower in comparison with the silages prepared without the additive (Zielinska et al., 2012).

\section{CONCLUSIONS}

Our study showed that it is important to identify and characterize industrial strains for individual features, because the effect of bacterial inoculants is dependent on strain characteristics and varies across the tested preparations. Among the many bacterial features, the most important from a technological point of view seems to be not only the efficiency of lactic acid and volatile fatty acids synthesis, the influence on aerobic stability, but also the antibiotic susceptibility of the strain, genetic stability and the ability to inhibit spoilage microorganisms.

Lactic acid bacteria strains in LK, LC, LB, and mix inoculants showed a positive influence on ensiling process and had effectively inhibited the growth of microorganisms prolonging the aerobic stability of silages. The most stable silage according to aerobic stability was silage treated with LB inoculant. In this silage, the highest concentrations of acetic acid, propionic acid, and 1,2-propanediol were reported. Number of yeast, moulds, Salmonella sp., $C$. perfringens, coliform bacteria, E. coli and Listeria sp. in inoculated-treated silages decreased in comparison to control one or in some cases those pathogens were eliminated. As microorganisms present in a starter culture can dominate the ensiling process and, for that reason, it is quite profitable to compose mixed inoculants consisting of several bacterial strains with different biotechnological features in appropriate proportions.

\section{LITERATURE CITED}

Aymerich, T., B. Martin, M. Garriga, M.C. Vidal-Carou, S. Bover-Cid, and M. Hugas. 2006. Safety properties and molecular strain typing of lactic acid bacteria from slightly fermented sausages. Journal of Applied Microbiology 100:4049. doi:10.1111/j.1365-2672.2005.02772.x.

Contreras-Govea, F.E., R.E. Muck, G.A. Broderick, and P.J. Weimer. 2013. Lactobacillus plantarum effects on silage fermentation and in vitro microbial yield. Animal Feed Science and Technology 179:61-68. doi:0.1016/j.anifeedsci.2012.11.008.

Danner, H., M. Holzer, E. Mayrhuber, and R. Braun. 2003. Acetic acid increases stability of silage under aerobic conditions. Applied and Environmental Microbiology 69:562-567. doi:10.1128/AEM.69.1.562-567.2003.

Davies, D.R., R.J. Merry, and E.L. Bakewell. 1996. The effect of timing of slurry application on the microflora of grass and changes occurring during silage fermentation. Grass and Forage Science 51:42-51. doi:0.1111/j.1365-2494.1996.tb02036.x.

Dimova, M.I. 2008. Some probiotic properties of bacteriocinogenic strain Lactobacillus plantarum UCM B-2705. Abstract. In $9^{\text {th }}$ Symposium on Lactic Acid Bacteria. 31 August-4 September. FEMS. Egmond aan Zee, The Netherlands.

Duniere, L., A. Gleizal, F. Chaucheyras-Durand, I. Chevallier, and D. Thevenot-Sergentet. 2011. Fate of Escherichia coli O26 in corn silage experimentally contaminated at ensiling, at silo opening, or after aerobic exposure, and protective effect of various bacterial inoculants. Applied and Environmental Microbiology 77:86968704. doi:10.1128/AEM.06320-11.

EFSA FEEDAP. 2011. Scientific opinion on the safety and efficacy of Lactobacillus buchneri (DSM 16774) as a silage additive for all species. EFSA Journal 9(9):2359. doi:10.2903/j.efsa.2011.2359.

EFSA FEEDAP. 2012. Guidance on the assessment of bacterial susceptibility to antimicrobials of human and veterinary importance. EFSA Journal 10(6):2740. doi:10.2903/j.efsa.2012.2740.

Holley, R.A., K.M. Arrus, K.H. Ominski, M. Tenuta, and G. Blank. 2006. Salmonella survival in manure-treated soils during simulated seasonal temperature exposure. Journal of Environmental Quality 35:1170-1180. doi:10.2134/jeq2005.0449.

Holzer, M., E. Mayrhuber, H. Danner, and R. Braun. 2003. The role of Lactobacillus buchneri in forage preservation. Trends in Biotechnology 21:282-287. doi:10.1016/S01677799(03)00106-9.

Honig, H. 1985. Determination of aerobic deterioration System Volkenrode - System Völkenrode - Institut für Grünland- und Futterpflanzenforschung der Bundesforschungsanstalt für Landwirtschaft Braunschweig-Völkenrode (FAL), Sonderdruck [in German].

Hudaa, N., P. Thompson, and C. Haiqiang. 2009. Elimination of Escherichia coli O157:H7 from alfalfa seeds through a combination of high hydrostatic pressure and mild heat. Applied and Environmental Microbiology 75:1901-1907. doi:10.1128/AEM.02531-08

Jatkauskas, J., V. Vrotniakiene, C. Ohlsson, and B. Lund. 2013. The effects of three silage inoculants on aerobic stability in grass, clover-grass, lucerne and maize silages. Agricultural and Food Science 22:137-144.

Klare, I., C. Konstabel, G. Werner, G. Huys, V. Vankerckhoven, G. Kahlmeter, et al. 2007. Antimicrobial susceptibilities of Lactobacillus, Pediococcus and Lactococcus human isolates and cultures intended for probiotic oral nutritional use. The Journal of Antimicrobial Chemotherapy 59:900-912. doi:10.1093/jac/dkm035.

Levital, T., A.F. Mustafa, P. Seguin, and G. Lefebvre. 2009. Effects of a propionic acid-based additive on short-term ensiling characteristics of whole plant maize and on dairy cow performance. Animal Feed Science and Technology 152:21-32. doi:10.1016/j.anifeedsci.2009.03.010. 
Magnusson, J., and J. Schnürer. 2005. Antifungal lactic acid bacteria as biopreservatives. Trends in Food Science and Technology 16:70-78. doi:10.1016/j.tifs.2004.02.014.

Markiewicz, L.H., E. Biedrzycka, E. Wasilewska, and M. Bielecka. 2010. Rapid molecular identification and characteristics of Lactobacillus strains. Folia Microbiologica 55:481-488. doi:10.1007/s12223-010-0080-z.

McDonald, P., A.R. Henderson, and S.J.E. Heron. 1991. The biochemistry of silage. Chalcombe Publications, Marlow, Bucks, UK.

Miecznikowski, A., K. Zielinska, A. Suterska, and K. Stecka. 2008. Sposób wytwarzania granulowanego preparatu bakterii fermentacji mlekowej. Patent no. PL 214654, Poland, Institute of Agricultural and Food Biotechnology 3.11.2008 [in Polish].

Muck, R.E., and L. Kung Jr. 1997. Effects of silage additives on ensiling. In Silage: Field to feedbunk. Northeast Regional Agricultural Engineering Service (NRAES), Ithaca, New York, USA.

Nawaz, M., J. Wang, A. Zhou, C. Ma, X. Wu, J.E. Moore, et al. 2011. Characterization and transfer of antibiotic resistance in lactic acid bacteria from fermented food products. Current Microbiology 62:1081-1089. doi:10.1007/s00284-010-9856-2.

Nikkhah, A. 2013. Barley forages for modern global ruminant agriculture: a review. Russian Agriculture Sciences 39:206-213. doi:10.3103/S1068367413030038.

Nishino, N., M. Yoshida, H. Shiota, and E. Sakaguchi. 2003. Accumulation of 1,2- propanediol and enhancement of aerobic stability in whole crop maize silage inoculated with Lactobacillus buchneri. Journal of Applied Microbiology 94:800-807. doi:10.1046/j.1365-2672.2003.01810.x.

Ohshima, M., E. Kimura, and H. Yokota. 1997. A method of making good quality silage from direct cut alfalfa by spraying previously fermented juice. Animal Feed Science and Technology 66:129137. doi:10.1016/S0377-8401(96)01111-x.

Oude Elferink, S.J.W.H., J. Krooneman, J.C. Gottschal, S.F. Spoelstra, F. Faber, and F. Driehuis. 2001. Anaerobic conversion of lactic acid to acetic acid and 1,2-propanediol of Lactobacillus buchneri. Applied and Environmental Microbiology 67:125-132. doi:10.1128/AEM.67.1.125-132.2001.

Ouoba, L.I., V. Lei, and L.B. Jensen. 2008. Resistance of potential probiotic lactic acid bacteria and bifidobacteria of African and European origin to antimicrobials: determination and transferability of the resistance genes to other bacteria International Journal of Food Microbiology 121(2):217-224. doi:10.1016/j.ijfoodmicro.2007.11.018.

Plengvidhya, V.,F. Breidt, and H.P.Fleming. 2004. Use of RAPD-PCR as a method to follow the progress of starter cultures in sauerkraut fermentation. International Journal of Food Microbiology 93:287296. doi:10.1016/j.ijfoodmicro.2003.11.010.

Purwin, C., L. Laniewska-Trokenheim, I. Warminska- Radyko, and J. Tywonczuk. 2006. Jakosc kiszonek - aspekty mikrobiologiczne, zdrowotne i produkcyjne. Medycyna Weterynaryjna 62:865-869 [in Polish].

Ranjit, N.K.L., and L. Kung Jr. 2000. Effect of Lactobacillus buchneri, Lactobacillus plantarum, or a chemical preservative on the fermentation and aerobic stability of corn silage. Journal of Dairy Science 83:526-535. doi:10.3168/jds.S0022-0302(00)74912-5.

Repetto, J.L., V. Echarri, M. Aguerre, and C. Cajarville. 2011. Use of fresh cheese whey as an additive for Lucerne silages: Effects on chemical composition, conservation quality and ruminal degradation of cell walls. Animal Feed Science and Technology 170:160-164. doi:10.1016/j.anifeedsci.2011.09.004.
Richard, E., N. Heutte, V. Bouchart, and D. Garon. 2009. Evaluation of fungal contamination and mycotoxin production in maize silage. Animal Feed Science and Technology 148(2-4):309-320. doi:10.1016/j.anifeedsci.2008.02.004.

Schmidt, W., R.J. Hu., E.E. McDonell, C.M. Klingerman, and L. Kung Jr. 2009. The effect of Lactobacillus buchneri 40788 or Lactobacillus plantarum MTD-1 on the fermentation and aerobic stability of corn silages ensiled two dry matter contents. Journal of Dairy Science 92:3907-3914. doi:10.3168/jds.2008-1788.

Skulimowski, J. 1974. Metody okreslania skladu pasz i ich jakosci, PWRL, Warsaw, Poland, [in Polish].

Taylor, C.C., J.A. Ranjit, J.M. Mills, J.M. Neylon, and L. Kung Jr. 2002. The effect of treating whole plant barley whit Lactobacillus buchneri 40788 on silage fermentation, aerobic stability and nutritive value for dairy cows. Journal of Dairy Science 85:17931800. doi:10.3168/jds.S0022-0302(02)74253-7.

Weissbach, F., und W. Laube. 1964. Beitrage zur Methodik der Garfuttruntersuchung und zur Durchfurung von Silierversuchen. Die Bestimming der Alkoholgehaltes im Garfutter. Landwirtsch. Versuchs. u Unters. Ves. 10:65-73 [in German].

You, Y., S.C. Rankin, H.W. Aceto, C.E. Benson, J.D. Toth, and Z. Dou. 2006. Survival of Salmonella enterica serovar Newport in manure and manure-amended soils. Applied and Environmental Microbiology 72:5777-5783. doi:10.1128/AEM.00791-06.

Zhang, T., L. Li, X. Wang, Z. Zeng, Y. Hu, and Z. Cui. 2009 Effects of Lactobacillus buchneri and Lactobacillus plantarum on fermentation, aerobic stability, bacteria diversity and ruminal degradability of alfalfa silage. World Journal of Microbiology and Biotechnology 25:965-971. doi:10.1007/s11274-009-9973-x.

Zielinska, K., A. Kapturowska, K. Stecka, M. Kuprys-Caruk, and A.Miecznikowski. 2012. Evaluation of potentially pathogenic bacteria presence in silages from meadow sward. Journal of Research and Applications in Agricultural Engineering 57(4):217-221 [in Polish].

Zielinska, K., and A. Miecznikowski. 2008. Kultury starterowe bakterii fermentacji mlekowej do kiszenia pasz - od selekcji szczepów do aplikacji. Monograph, Warsaw Agricultural and Food Biotechnology, Warsaw, Poland, [in Polish].

Zielinska, K., R. Sawicka-Zukowska, K. Stecka, A. Miecznikowski, and A. Suterska. 1995. Nowy szczep Lactobacillus plantarum K KKP/593/p. Patent nr PL 179838, Poland, Institute of Agricultural and Food Biotechnology 6.09.1995 [in Polish].

Zielinska, K., K. Stecka, M. Kuprys, A. Kapturowska, and A Miecznikowski. 2011. Ocena stopnia skazenia bakteriami patogennymi runi lakowej i gleb nawozonych plynnymi nawozami organicznymi. Journal of Research and Applications in Agricultural Engineering 56(4):212-215 [in Polish].

Zielinska, K., K. Stecka, A. Miecznikowski, A. Suterska, and M. Kuprys. 2006. Nowy szczep bakterii Lactobacillus buchneri. Patent nr PL 209677, Poland. Institute of Agricultural and Food Biotechnology 2.08.2006 [in Polish].

Zielinska, K., A. Suterska, and A. Miecznikowski. 1998. Nowy szczep bakterii Lactobacillus plantarum C. Patent nr PL 190162, Poland, Institute of Agricultural and Food Biotechnology 2.12.1998 [in Polish]. 